\title{
Intentionality of women's actions in labor: a study in social phenomenology
}

\author{
Intencionalidade das ações de mulheres no trabalho de parto: estudo na fenomenologia social \\ Intencionalidad de las acciones de las mujeres en el trabajo: un estudio en fenomenología social
}

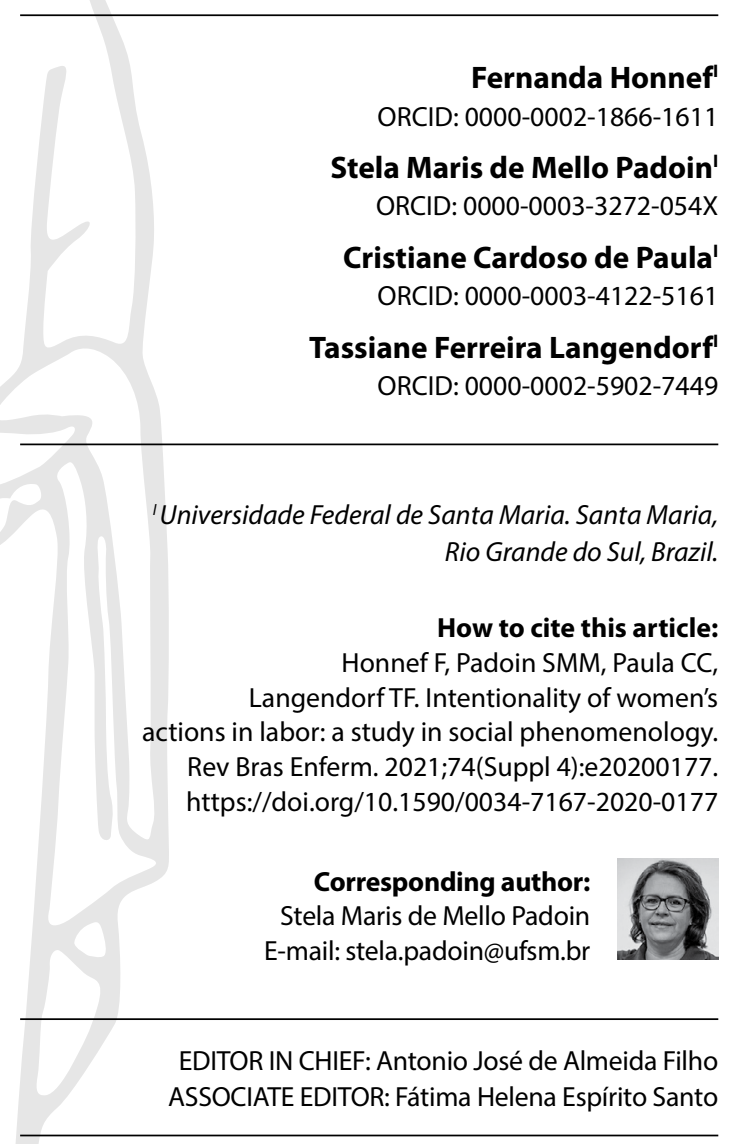

Submission: $07-13-2020$

Approval: $11-08-2020$

\begin{abstract}
Objective: to understand the intentionality of women's autonomous actions in labor. Methods: a study in Alfred Schütz's social phenomenology, developed with 15 puerperal women admitted to a university hospital in southern Brazil. Data were collected through phenomenological interviews and analyzed according to the adopted framework and the comparison with scientific productions. Results: the actions intended to receive physical and emotional support from their companions, from pregnancy, for a peaceful delivery with less pain, fast and without interventions. The intention was to do the right things for the child's well-being and, after delivery, to be painless and active to take care of their children. Final considerations: women's actions have intentionality arising from their knowledge, which is guided by the social relationships established in the world of life.

Descriptors: Labor, Obstetric; Women; Personal Autonomy; Qualitative Research; Nursing.
\end{abstract}

\section{RESUMO}

Objetivo: compreender a intencionalidade das ações autônomas das mulheres no trabalho de parto. Métodos: estudo na fenomenologia social de Alfred Schütz, desenvolvido com 15 puérperas internadas em um hospital universitário na Região Sul do Brasil. Os dados foram coletados por entrevista fenomenológica e analisados conforme o referencial adotado e o cotejamento com produções científicas. Resultados: as ações intencionaram receber apoio físico e emocional do acompanhante, desde a gestação, para um parto tranquilo com menos dor, rápido e sem intervenções. A intencionalidade foi fazer as coisas certas para o bem-estar do filho e, após o parto, estar sem dor e ativa para cuidar do(s) filho(s). Considerações finais: as ações das mulheres têm intencionalidades oriundas de sua bagagem de conhecimento, a qual é pautada nas relações sociais estabelecidas no mundo da vida.

Descritores: Trabalho de Parto; Mulheres; Autonomia Pessoal; Pesquisa Qualitativa; Enfermagem.

\section{RESUMEN}

Objetivo: comprender la intencionalidad de las acciones autónomas de las mujeres en el trabajo de parto. Métodos: estudio de la fenomenología social de Alfred Schütz, desarrollado con 15 puérperas ingresadas en un hospital universitario del sur de Brasil. Los datos fueron recolectados a través de entrevistas fenomenológicas y analizados según el marco adoptado y la comparación con las producciones científicas. Resultados: las acciones destinadas a recibir apoyo físico y emocional de la acompañante, desde el embarazo, para un parto tranquilo, con menos dolor, rápido y sin intervenciones. La intención era hacer lo correcto para el bienestar del niño $y$, después del parto, ser indoloro y activo para cuidar al niño. Consideraciones finales: las acciones de las mujeres tienen intencionalidades derivadas de su bagaje de conocimientos, que se fundamenta en las relaciones sociales que se establecen en el mundo de la vida.

Descriptores: Trabajo de Parto; Mujeres; Autonomía Personal; Investigación Cualitativa; Enfermería. 


\section{INTRODUCTION}

The development of nursing as a science permeates the role of nurses inserted in women and family care from reproductive planning, pregnancy, parturition, and puerperium. In this field of knowledge, the profession leads changes when developing care and the possibilities of reducing unnecessary interventions in obstetric care, considering women in the foreground ${ }^{(1)}$.

Such interventions come from the institutionalization of childbirth at the beginning of the $20^{\text {th }}$ century, when it started to be conceived as an object of medical knowledge and practice to the detriment of meanings and senses of childbirth for women ${ }^{(2)}$. From then on, their decisions were anchored in medical knowledge and technologies, leaving the idea of childbirth as a physiological event in the background and carried out by women ${ }^{(2-4)}$.

These interventionist practices have often made this setting a cause of suffering for women, in addition to increasing the risks of maternal morbidity and mortality in childbirth and birth by disregarding scientific indication ${ }^{(1-4)}$. Morbidity and mortality rates show that quality of obstetric care does not converge with the institutionalization of childbirth ( $98 \%$ of births in hospitals) or with high prenatal coverage ${ }^{(5)}$. It is worth remembering that the maternal mortality ratio in 2015 was 60 deaths per 100 thousand live births in Brazil, which is well above the 35 deaths per 100 thousand live births recommended by the World Health Organization (WHO) ${ }^{(6-7)}$.

To improve this setting, governmental actions were implemented at an international level based on indication of practices based on best scientific evidence. Among the actions, the WHO publication in 1996, which was reaffirmed in 2018, makes recommendations regarding using obstetric practices ${ }^{(8)}$. The publication even asserts that women's decision-making anchored in the physiology of parturition and the expansion of social actors in this setting is restored. This should cover nursing, since the insertion of nurse-midwives contributed to the qualification of this care, including the reduction of interventions $s^{(9)}$. Such actions contribute to the goal of reducing maternal mortality to 20 deaths per 100 thousand live births, established by the UN in the Sustainable Development Goals ${ }^{(10)}$.

In Brazil, since the beginning of the $20^{\text {th }}$ century, the Ministry of Health has proposed policies and legislation based on WHO guidelines, with a view to qualifying obstetric care. The propositions are based on evidence-based practice ${ }^{(11)}$. However, there are difficulties for the effective implementation of programs and adequacy of health services, which include administrative, social, economic and cultural issues, in addition to consolidated practices, often based on the convenience of health professionals and institutions ${ }^{(11-12)}$.

Among the aspects to be overcome, there is a need to consider the demands of the social actors involved, and especially the role of women and their families ${ }^{(13-14)}$. Such leadership in labor and childbirth spaces permeates recognizing the Brazilian sociocultural issue that may be expressed in the birth plan meanings, its constituent elements and in positive birth experiences ${ }^{(13)}$. Thus, understanding the intentionality of women's actions allows us to glimpse what aspects are present in their actions and how they can be incorporated during labor.
To achieve this goal, Alfred Schütz's social phenomenology theoretical framework is listed as a guiding thread for understanding the human actions inscribed in a social world or world of life, which are influenced by it ${ }^{(15)}$. This framework focuses on the premise of the existence of an intentional meaning in all actions. This intentionality is based on future projects and expectations (reasons for) and come from present and past experiences (reasons why). This motivation results in typical characteristics of a given social group ${ }^{(15)}$.

\section{OBJECTIVE}

To understand the intentionality of women's autonomous actions in labor.

\section{METHODS}

\section{Ethical aspects}

This research was approved by the Research Ethics Committee of the study institution and met all the rules foreseen for research carried out on human beings, with the ethical precepts being formalized by signing the Informed Consent Form and maintaining participant anonymity (alpha identification numeric), in compliance with Resolution 466/12 of the Brazilian National Health Council (Conselho Nacional de Saúde).

\section{Theoretical-methodological framework}

Alfred Schutz's social phenomenology theoretical-methodological framework supported the study, since its main theoretical assumption is the understanding of motivations of actions of a social group ${ }^{(15)}$. The motivations of individuals in a particular group are based on present and past experiences (reasons why and/or reasons) and future projects (reasons for). The first is related to their experiences in the world of life or the experiences shared with their contemporaries, and is based on their knowledge that biographically situates individuals. The second evokes the possibility of analyzing actions' intentions, which are the perspectives of the future (reasons for).

The focus of this study was to seek the understanding of women's autonomous actions, anchored in intentionality to meet their expectations (what they had in mind) considering puerperal women as a social group.

\section{Type of study}

This is a qualitative study of a phenomenological nature. The COnsolidated criteria for REporting Qualitative research (COREQ) was used, as it offers consolidated criteria for writing qualitative research, promoting complete and transparent reports.

\section{Methodological procedures, study setting and data sources}

The study was conducted at a rooming-in of a university hospital, where a multidisciplinary team works to meet pregnant women's and high-risk women's demands (tertiary health care level) from the central region of Rio Grande do Sul State. For this reason, this hospital is considered a reference in the integration with the Unified Health System (SUS - Sistema Único de Saúde). 
In this setting, the researcher made the approach and setting in order to know the rooming-in's routine, medical record organization, listing a room to carry out the interviews aiming at privacy and anonymity. Information was sought from puerperal women's medical record to identify those who met the inclusion criteria (women within a week after delivery, with assisted labor at the study's setting institution). Thus, the enrollment of study participants took place intentionally, at which time the exclusion criteria were considered (puerperal women with indication for cesarean section, severe maternal pathologies or fetal death). A list of possible participants who were hospitalized in the institution, setting of this study, and who met the inclusion criteria, with the potential to provide information relevant to the object of study, was composed.

\section{Data collection and organization}

The interview technique occurred with an individual approach between September and December 2017 through phenomenological interview ${ }^{(16)}$. Participants were invited to move to a reserved room in the rooming-in and. After clarifying about the research, their consent was requested to start the interview from an informal conversation. So it was necessary to talk with women about where and with whom their newborn would be so that they would feel more comfortable. Some were accompanied by their children and others left them with their companions in the rooming-in. It is noteworthy that four women refused to participate, as they said that remembering the moment of childbirth was not something of interest to the negative aspects that it would bring to remember the suffering experienced.

The environment aspects were favorable to develop the interview that was mediated by empathy, intersubjectivity and phenomenological attitude, in which the researcher needed to decentralize herself to focus on the understandings of the research participants in a one-to-one relationship, without any object between researcher and participant. This enabled each woman to express her motivations. For the interviews, a script was prepared with open-ended questions that focused on the research problem and contemplated the adopted theoretical framework. Due to the accumulated experience of research in phenomenology, we believe it is necessary that the questions be tested in the first interviews and applied only after adjustments. After this procedure, the interview started with the question: "Tell me about the birth and delivery process", "What did you do during this process?" and "Did you feel participatory?"Then, the guiding phenomenological question was: "What did you have in mind when you performed such an action?"

The content conduct in this type of interview is carried out by the individuals interviewed, in which the researcher identifies actions in the reports and deepens the understanding of the meaning of those actions and their intentionality. For this reason, in the interviews ${ }^{(16)}$, keynotes were taken from those reported, seeking to reveal the motivations of women's autonomous actions childbirth and birth. By autonomous actions or autonomy, we mean the freedom to act for itself in a participatory way. With the authorization of the interviewees, the statements were audio recorded, which allowed the researcher to be freer to listen to them and allowed the expression of their expressions. The interviews took between 15 and 30 minutes.

The statements were transcribed in full and carefully read to begin analysis of these results, which occurred concurrently with data production. Data collection ended when there was convergence and sufficiency of meanings, in the $15^{\text {th }}$ interview, when the objective for understanding the studied object was reached ${ }^{(17)}$.

\section{Data analysis}

Analysis was developed from reading the interviews to identify the intentionality (reasons for) of actions of women in labor. "Reasons for" were grouped by similarity of meaning, and a synthesis was elaborated in concrete categories of experience ${ }^{(14)}$. Thus, the concrete categories of experience of reasons for were three (03): They expect to receive physical and emotional support from their companion; They want a peaceful delivery, with less pain, fast and without interventions; They intend to do the right things so that, after birth, they are pain-free and active to care for their children.

Data were analyzed and the results were interpreted according to the foundations of Alfred Schütz's sociological phenomenology. Then, the results were compared with national and international literature on the topic to clarify and understand the phenomenon of female autonomy in labor.

\section{RESULTS}

Participants were between 18 and 36 years old, and worked as housewives, baker's assistants, secretaries, psychologists, maids. More than half had already had children, and of these, all had a normal delivery.

As for category 1, to receive physical and emotional support, women choose someone they trust to accompany labor. This choice is made during pregnancy or only when they arrive at the hospital, as the institution requires them. In fact, one of the reasons is to strengthen family ties. Despite these motivations, women have ambiguous actions, sometimes they intend support and sometimes ask their companions to leave the delivery room.

With motivation to have a peaceful delivery, with less pain, fast and without interventions, which concerns category 2 , women seek information about the parturition process with close people (mother, sisters, friends) and with health professionals. With this intentionality, they also develop oriented physical activities during pregnancy (Pilates) and/or after arriving at the hospital during labor (walking, squatting, hot bath, use of birthing stool, Swiss ball, and music).

As for category 3 , the intentionality of doing the right things is aimed at the postpartum period, whether for the child's wellbeing or for them to be pain-free and active to care for them. Women try to achieve ideal behavior, which they understand must be convergent with the conduct and performance that professionals expect from them during labor. They even identify that excessive expression of their emotions (anxiety, nervousness and pain) goes against the ideal behavior.

It appears that women's actions during labor are based on the intention to feel support so that childbirth is a moment shared with their families and that they are supported to perform their autonomy, which is related to the information accessed until the moment of delivery. On the other hand, when entering the hospital, actions are shared with professionals who are there. To perform autonomy, they need to transpose what is seen as the ideal behavior expected from professionals. 
Chart 1 shows clippings of the illustrative statements and the code of other participants who also reported such intentionality, grouping by similarity of meanings composes concrete categories of experience.

Chart 1-Concrete categories of experience and excerpts from statements, 2017

\begin{tabular}{|l|l|}
\hline \multicolumn{2}{|l|}{ CONCRETE CATEGORIES OF EXPERIENCE - REASONS FOR } \\
\hline $\begin{array}{l}\text { They expect to receive physical and emotional support from } \\
\text { their companion }\end{array}$ & Code \\
\hline $\begin{array}{l}\text { [...] at the time I wanted it to be him [...] for him to see what the } \\
\text { process is like, because many men don't know it. It is easy to } \\
\text { get home with the baby in her arms [...] it is good for them, the } \\
\text { parents, to participate. [...] helped by holding my hand. (P1) }\end{array}$ & \\
$\begin{array}{l}\text { Yes, I said that he would stay with me all the time. Poor him, } \\
\text { because he was with me all the time, so I started to feel a lot of } \\
\text { pain, I started to get very nervous. He kept looking at me that } \\
\text { made me nervous, l asked him to leave. (P3) }\end{array}$ & (P7); \\
$\begin{array}{l}\text { The presence of my boyfriend was also essential, he was there } \\
\text { beside me, giving me strength. [...] stood by my side, holding my } \\
\text { hand, every moment saying that it was not to give up, that it was } \\
\text { to keep pushing, that it was already coming. (P4) }\end{array}$ & (P13) \\
$\begin{array}{l}\text { He wanted it [...] he helped me by doing a back massage to relieve } \\
\text { it a little [...] this is already a comfort. I was afraid of winning } \\
\text { alone [...], but he can stay with me that gives me a relief, a sense of } \\
\text { security, that you can count on someone at that time. (P10) }\end{array}$ & \\
\hline $\begin{array}{l}\text { They want a peaceful delivery, with less pain, fast and } \\
\text { without interventions }\end{array}$ & \\
\hline
\end{tabular}

At home, I took a hot shower to help induce labor and relax. [...] I was about 20 min under the shower with water hitting my back, relax a lot. (P1)

During pregnancy, every day l looked for something new to be researching and finding out about. [...] to find out, if something happens outside of that, you know how to handle the situation, what you have to do or stop doing, then you keep updating yourself, otherwise you will be left behind. I was informed by the anxiety of arriving at the moment [...], as much as I have my experience of 5 daughters, today the world evolves very fast. (P3)

I've always done Pilates, weight training, I've always been prepared for normal birth. [...] thought it would be easier, because of the preparation before, but at the time it's not quite what l imagined [...] I started pilates because of my pregnancy. (P8)

I read it, l looked in articles and my doctor also said that if I was feeling good, I could walk, do the squat exercises in the chair. (P15)

They intend to do the right things so that, after birth, they are pain-free and active to care for their children

There are mothers who arrive very anxious to deliver, see the baby, arrive at the hospital very early, [...] sometimes it is not time, [...] but with $2 \mathrm{~cm}, 3 \mathrm{~cm}$, there the mother does not feel pain, they end up putting in the serum. (P1)

They said "ah, but you will be calm, you already had 5 children" - you could have 10 don't change [...]. I felt bad, ashamed, for always having this myth, I said I feel ashamed. [...] the doctor taught me. (P3)

I had not yet felt anything of contraction, [...] / did not know the quantity, how was the strength I had to make. [...] / wanted to talk to him [doctor] at the time of delivery, he said no, to be fasteryou know, it was taking too long, I had to help if she wasn't going to be born. (P4)

I arrived here not knowing anything. [...] I didn't even know how to do [...] they spoke to help me push [...]. When they spoke, I always helped. (P11)

\section{DISCUSSION}

The intentionality of women's actions during labor was related to their biographical situation. In social phenomenology, this situation is constructed throughout life, based on experiences in the world of life, which constitute their knowledge and their system of interest ${ }^{(15)}$. Thus, the women in this study had experiences related to the parturitive process in their biographical situation, both from their previous births and from what they heard about in their social relationships.

Their knowledge comprises the information that the women in this study sought during pregnancy to meet their desires and, with this, gave meaning and (re) signified aspects of childbirth and birth. Therefore, it is understood that women's actions during labor were based on a project that they created during their lives. For phenomenology, the project is foreseeing a future conduct (action) ${ }^{(15)}$. Women imagine a future action, even during pregnancy and, thus, establish projects for the delivery process to occur as imagined. These projects motivate their actions and make their role possible.

It is noteworthy that, between the project or foreseeing and human action, there is a link, a path that leads to this fulfillment ${ }^{(15)}$. It was in this way that women accessed their social relationships in the study on screen. These relationships took place with health professionals and their families, someone they trust, with a view to helping to achieve the idealized/projected, which was to receive support at delivery time.

\section{They expect to receive physical and emotional support from their companion}

With the intention of receiving physical and emotional support from their companion, this was chosen during pregnancy, being expected by pregnant women to have a person they trust on their side. To this end, in this choice, aspects such as affective bond and knowledge of people and their relationships were taken into consideration for the companion's choice action.

In this study, a partner was chosen by most of interviewees, for their presence during prenatal care and for having participated in previous births. Studies indicate that the presence of a partner in prenatal consultations has an impact on satisfaction with the support received during labor ${ }^{(18)}$ and also on the security to perform support in actions planned by women ${ }^{(19)}$. However, there are other participants in this study who chose women from their social relationship, such as their mothers and sisters, as they already had knowledge about the process of childbirth and birth.

Companions' actions were significant for assistance, support to provide affection, attention and anxiety control, in addition to promoting the reduction of practices not guided by best evidence, such as food restriction and movement. During delivery, the presence provided conditions for non-lithotomic position, skin-to-skin contact and reduced Kristeller's maneuver ${ }^{(20)}$.

The place's characteristics where this study was carried out ensured for all of them the presence of a companion of their choice, in line with the indication supported by legislation since $2005^{(21)}$. According to indications that deal with good practices in care for childbirth and birth, such as those of $\mathrm{WHO}$ and $\mathrm{MoH}^{(8,22)}$, 
such practice should be encouraged. However, it should be noted that this reality is not evident in other places. Cross-sectional research data showed that $89 \%$ of the studied population had their birth in the public sector and that the presence of a companion was guaranteed for $51.7 \%$ of women, reduced delivery time to $39 \%{ }^{(20)}$. Another study that described the results of childbirth care after the implementation of Rede Cegonha and Nascer Saudável programs showed that the presence of a companion increased in public sectors, but in the private sector it is still small $(12.5 \%)^{(23)}$.

$\mathrm{MoH}$ and $\mathrm{WHO}$ indications are based on the benefits that companions, through their actions, will promote, among which, childbirth with less interventions and more peaceful, due to the emotional and physical support received ${ }^{(8,22)}$. However, these indications did not include the preparation of this actor, as evidenced in women's statements regarding the unpreparedness of their companions, pointing out that their preparation would be necessary for this actor to meet the expectations of women in the delivery setting. Parents showed great expectations and curiosity related to their role during labor and showed an increasing interest and commitment to participate and get involved in training sessions for preparation for childbirth ${ }^{(18)}$.

A study points out that knowledge about the right to the presence of a companion should permeate prenatal consultations, as the said study showed that women received information about the companion's right in inpatient units and less than 20\% reported that this information was given during prenatal ${ }^{(24)}$.

Culturally, companions still receive little information to compose their knowledge and understand how to act during the delivery process to perform actions that promote the exercise of female autonomy and their role. Otherwise, when this actor is prepared, he or she can assist in the exercise of female autonomy, promoting self-confidence and questioning professional practices ${ }^{(25)}$.

\section{They want a peaceful delivery, with less pain, fast and without interventions}

For a smooth delivery, with less pain, fast and without interventions, women prepare themselves during pregnancy, from the search for information, to support their choices and familiarization with the delivery process. In this action, according to assumptions of social phenomenology, women have a project in mind and stop acting in their natural attitude to have a reflective attitude. They highlight in their knowledge learned experiences, which are accessed for planning actions with a view to attending to their project ${ }^{(26)}$.

In the study, this attitude was evidenced in the search for information through research in newspapers, the internet and in the relationship with social actors in women's daily lives such as professionals, friends and family. This exchange of information between social actors is mediated by a one-to-one relationship established in a direct experience between people permeated by intersubjectivity ${ }^{(15)}$.

The construction of women's desires about ways of giving birth begins when imagining the pregnancy comes to fruition. At that moment, all of their internalized knowledge about ways of giving birth becomes the background against which intentions are projected ${ }^{(27)}$. In this context, a sum of both empirical and scientific learning is built, which can contribute to women and their family to fully experience the pregnancy-puerperal period ${ }^{(28-29)}$.
Thus, the support found in information about childbirth physiology in different relationships established is essential for women to believe in their ability to give birth, and also, when experienced during pregnancy, to promote and strengthen their autonomy ${ }^{(30)}$. In a randomized clinical trial, the intervention during pregnancy about the evolution of stages of labor, interventions and their indications helped to experience this moment with less fear $^{(31)}$. Thus, it is essential that surrounding information in the world of life prepare women to perform their autonomy by making conscious choices so that they can develop the knowledge, attitudes, skills and necessary self-knowledge and effectively take the responsibility for all decisions made during childbirth ${ }^{(31)}$.

Choosing vaginal birth converged with the intention of a smooth delivery and without interventions. This understanding was evidenced in a qualitative study in which women associated normal birth with a natural process and with the benefits provided to women and babies ${ }^{(32)}$.

Another aspect that permeated the actions of the women in the study on screen was the intention of pain relief. A study carried out to understand women's experiences with the pain of labor showed that actions depend on the meaning attributed to pain by them. When they signify pain as productive and with a purpose, it is associated with positive cognitions and emotions, on the other hand, when conceiving pain as threatening, they tend to feel that they need help from external pain control methods ${ }^{(33)}$.

In this study, women performed pain relief actions to promote dilation, which converge with $\mathrm{WHO}$ and $\mathrm{MoH}$ recommendations. Liquid supply, the adoption of vertical positions and freedom of movement, seeking to increase maternal comfort and facilitate the progression of labor, and the use of non-pharmacological methods of pain relief, should be encouraged for labor management ${ }^{(8,12,22)}$.

The presence of qualified professionals to encourage good practices was observed to be beneficial for qualification of obstetric care. A cross-sectional observational study identified an increase in good practices in assisting the parturition process in institutions where nurse-midwives were present ${ }^{(30)}$.

\section{They intend to do the right things so that, after birth, they are pain-free and active to care for their children}

With the perspective of doing the right things so that after birth they are pain-free and active to care for their children, through ideal behavior, their actions are aimed at not causing inconvenience to the hospital and professionals. In this sense, they refer that the excessive expression of their emotions, such as anxiety, pain and nervousness may not be beneficial, and that their actions must converge with what, in their conception, professionals consider ideal. This process was referred to in women's statements about how to do the right things.

In their natural attitude, women act according to their ideal behavior, which in their conception is expected of them by professionals. This conception is the result of institutionalization of childbirth, with which professionals took control of childbirth and birth and hierarchies are established in this process. For Alfred Schütz, hierarchies of superiority and subordination are naturally accepted in all contexts, being social inheritances that guide individuals. These aspects determine the conduct of 
individuals in the world of life and add traces of common sense to their actions ${ }^{(15)}$.

In the context of obstetric care, such social inheritances are related to the institutionalization of childbirth, in which abusive and unnecessary interventionist practices are widely used, without privacy and respect for the will of women subjected to strict routines ${ }^{(12)}$. In this investigation, it was possible to infer that women tried to control their physiology during labor to follow the rhythm of labor recommended by professionals.

In this sense, time control and the dynamics imposition of labor explain the excessive rate of interventions, including cesarean sections, making obstetric care in Brazil focused on the decision of health professionals and not on the physiology of women's bodies ${ }^{(34-35)}$. Despite efforts to modify this setting, which emphasizes the idea of women's passivity before interventions that shorten birth time, the cultural essence in which such behaviors are submerged, in fact, are practices of power over women's body, implicitly, they determine how it should act, position itself and even express itself during its delivery experience. These experiences are passed intergenerationally over time and are accepted naturally, making it difficult to change behavior ${ }^{(34,36)}$.

\section{Study limitations}

Setting's and participants' characteristics stand out among the limitations of this study. As for the first, we understand that data generation having been developed in a single setting may reflect the intentionality of women's actions in labor determined, including the context of the population and the characteristics of that service and the professionals who work there. As for the population of women up to one week after delivery, which indicates a period that favors the memory of recently experienced labor, we understand that they are under the influence of physiological changes and adaptation to care for themselves, newborns and family, which can influence data generation.

\section{Contributions to nursing, health and public policies}

Understanding the intentionality of women's actions in labor contributes to qualify obstetric care by presenting the motivations since the choice of a companion who will offer support, the type of delivery and the activities of their choice during labor. This evidence contributes to the role of nurses who develop care for women and their families from reproductive planning, pregnancy, parturition, and puerperium.

Understanding women's perspectives contributes to humanization of childbirth and birth by promoting that they are the main focus of care. Recognizing that women's intention is to do the right things, both for the child's well-being and for their recovery after childbirth, can contribute to their role, decentralizing convenience practices of professionals and health institutions. The results of this study provide evidence for teams to discuss obstetric settings that involve respect and support for their actions and expectations of having a peaceful delivery, with less pain and faster. These practices can even reduce unnecessary interventions and, perhaps, contribute to the reduction of maternal mortality, contributing to the response to the Sustainable Development Goals.

\section{FINAL CONSIDERATIONS}

The study's findings demonstrate that the intentionality of women's autonomous actions emerges from their knowledge that composes a projection of how they would like childbirth to occur. Therefore, it will be important for health professionals to provide subsidies for women to achieve a plan that is still idealized, culminating in the development of a birth plan, anchored in the reciprocity of user and professional interests.

Positive experiences make up women's knowledge and when they are added to the evidence and good practices for normal childbirth, they reflect on a reflexive attitude that will make it possible to rescue the protagonism and autonomy of women in labor and thus modify the context of obstetric care.

\section{FUNDING}

The present study was carried out with support from the Higher Education Personnel Improvement Coordination - Brazil (CAPES - Coordenação de Aperfeiçoamento de Pessoal de Nível Superior) - Financing Code 001.

\section{REFERENCES}

1. Parada CMGL. Women's health during pregnancy, childbirth and puerperium: 25 years of recommendations from international organizations. Rev Bras Enferm [Internet]. 2019 [cited 2020 Mar 07];72(Suppl 3):1-2. Available from: https://www.scielo.br/pdf/reben/ v72s3/0034-7167-reben-72-s3-0001.pdf

2. Santos FSR, Souza PA, Lansky S, Oliveira BJ, Matozinhos FP, Abreu ALN, et al. Os significados e sentidos do plano de parto para as mulheres que participaram da Exposição Sentidos do Nascer. Cad Saúde Pública [Internet]. 2019 [cited 2020 Mar 12];35(6): e00143718. Available from: https://www.scielo.br/pdf/csp/v35n6/1678-4464-csp-35-06-e00143718.pdf

3. Rodrigues TFCS, Monteschio LVC, Cismer E, Decesaro MN, Serafim D, Marcon SS. Motivations for planned home birth: an exploratory descriptive study. O Braz J Nurs [Internet]. 2018 [cited 2020 Sep 16];17(2). Available from: http://www.objnursing.uff.br/index.php/nursing/ article/view/5891/html

4. Marins RB, Cecagno S, Gonçalves KD, Braga LR, Ribeiro JP, Soares MC. Care techniques for pain relief in birthing. Rev Pesqui: Cuid Fundam [Internet]. 2020 [cited 2020 Mar 07];12:275-80. Available from: http://seer.unirio.br/index.php/cuidadofundamental/article/view/8502/pdf

5. Declercq E. Childbirth in Brazil: challenging an interventionist paradigm. Birth [Internet]. 2015 [cited 2020 Mar 29];42:1-4. Available from: https://onlinelibrary.wiley.com/doi/full/10.1111/birt.12156 
6. World Health Organization (WHO). Strategies toward ending preventable maternal mortality (EPMM) [Internet]. 2015 [cited 2020 Mar 20]. Available from: https://apps.who.int/iris/bitstream/handle/10665/130776/WHO_RHR_14.21_eng.pdf;jsessionid=E303EEB87A5164C29DFF1 B98C75591E4?sequence $=1$

7. Ministério da Saúde (BR). Objetivos de Desenvolvimento do Milênio: Relatório Nacional de Acompanhamento [Internet]. Instituto de Pesquisa Econômica Aplicada e Secretaria de Planejamento e Investimentos Estratégicos; supervisão: Grupo Técnico para o acompanhamento dos ODM. Brasília: Ipea: MP, SPI, 2014 [cited 2020 Mar 10]. Available from: https://www.ipea.gov.br/portal/index. php?option=com_content\&id=22538

8. World Health Organization (WHO). World Health Organization recommendations: intrapartum care for a positive childbirth experience [Internet]. Geneva: World Health Organization. 2018 [cited 2020 Mar 12]. Available from: http://apps.who.int/iris/bitstre am/10665/250796/1/9789241549912-eng.pdf?ua=1

9. Medeiros RMK, Teixeira RC, Nicolini AB, Alvares AS, Corrêa ACP, Martins DP. Humanized Care: insertion of obstetric nurses in a teaching hospital. Rev Bras Enferm [Internet]. 2016 [cited 2020 Mar 12];69(6):1029-36. Available from: https://www.scielo.br/pdf/reben/v69n6/0034 7167-reben-69-06-1091.pdf

10. United Nations. Sustainable Development Goals. New York: United Nations [Internet]. 2015 [cited 2020 Jan 13]. Available from: https:// sustainabledevelopment.un.org

11. Velho MB, Brüggemann OM, McCourt C, Gama SGN, Knobel R, Gonçalves AC, et al. Modelos de assistência obstétrica na Região Sul do Brasil e fatores associados. Cad Saúde Pública [Internet]. 2019 [cited 2020 Mar 13];35(3):e00093118. Available from: https://www.scielo.br/pdf/ csp/v35n3/1678-4464-csp-35-03-e00093118.pdf

12. Niy DY, Oliveira VC, Oliveira LR, Alonso BD, Diniz CSG. Overcoming the culture of physical immobilization of birthing women in Brazilian healthcare system? findings of an intervention study in São Paulo, Brazil. Interface (Botucatu) [Internet]. 2019 [cited 2020 Mar 12];23:e180074. Available from: https://www.scielo.br/pdf/icse/v23/en_1807-5762-icse-23-e180074.pdf

13. Pereira SB, Diaz CMG, Backes MTS, Ferreira CLL, Backes DS. Good practices of labor and birth care from the perspective of health professionals. Rev Bras Enferm [Internet]. 2018 [cited 2020 Mar 10];71(suppl 3):1393-9. Available from: https://www.scielo.br/pdf/reben/ v71s3/0034-7167-reben-71-s3-1313.pdf

14. Kamali S, AhmadianL, Khajouei R, Bahaadinbeigy K. Health information needs of pregnant women: information sources, motives and barriers. Health Info Libr J[Internet]. 2018 [cited 2020 Mar 12];35(1):24-37. Available from: https://onlinelibrary.wiley.com/doi/abs/10.1111/ hir.12200

15. Schutz A. Sobre fenomenologia e relações sociais. Petrópolis, RJ: Vozes; 2012. 357 p.

16. Guerrero-Castañeda RF, Menezes TMO, Ojeda-Vargas MG. Characteristics of the phenomenological interview in nursing research. Rev Gaúcha Enferm [Internet]. 2017 [cited 2020 Mar 12];38(2):e67458. Available from: https://www.scielo.br/pdf/rgenf/v38n2/en_0102-6933rgenf-1983-144720170267458.pdf

17. Minayo MCS. Amostragem e saturação em pesquisa qualitativa: consensos e controvérsias. Rev Pesqui Qualit [Internet]. 2017 [cited 2020 Mar 12];5(7):01-12. Available from: https://editora.sepq.org.br/index.php/rpq/article/view/82/59

18. Holanda SM, Castro RCMB, Aquin PS, Pinheiro AKB, Lopes LG, Martins ES. Influence of the partner's participation in the prenatal care: satisfaction of primiparous women regarding the support in labor. Texto Contexto Enferm [Internet]. 2018 [cited 2020 Mar 12];27(2):e3800016. Available from: https://www.scielo.br/pdf/tce/v27n2/en_0104-0707-tce-27-02-e3800016.pdf

19. Souza MAR, Wall ML, Thuler ACM, Souza SRRK. Prenatal as a facilitator in the participation of companions during labor and delivery process. Rev Pesqui: Cuid Fundam[Internet]. 2020 [cited 2020 Mar 29];12:196-201. Available from: http://www.seer.unirio.br/index.php/ cuidadofundamental/article/view/7201/pdf

20. Monguilhott JJC, Bruggemann OM, Freitas PF, D'orsi E. Nascer no Brasil: the presence of a companion favors the use of best practices in delivery care in the South region of Brazil. Rev Saúde Pública. 2018;52(1). Available from: https://doi.org/10.11606/ s1518-8787.2018052006258

21. Presidência da República (BR). Lei n.11.108, de 07 de abril de 2005. Altera a Lei 8.080, introduzindo o direito ao acompanhante de escolha durante o trabalho de parto, no parto e no pós-parto imediato [Internet]. Diário Oficial da União, Brasília. 2005 [cited 2020 Jan 29]. Available from: http://www.planalto.gov.br/ccivil_03/_Ato2004-2006/2005/Lei/L11108.htm

22. Ministério da Saúde (BR). Secretaria de Ciência, Tecnologia e Insumos Estratégicos. Departamento de Gestão e Incorporação de Tecnologias em Saúde. Diretrizes nacionais de assistência ao parto normal: versão resumida [Internet]. Brasília. 2017 [cited 2020 Feb 02]. Available from: https://bvsms.saude.gov.br/bvs/publicacoes/diretrizes_nacionais_assistencia_parto_normal.pdf

23. Leal MC, Bittencourt AS, Esteves-Pereira AP, Ayres BVS, Silva LBRAA, Thomaz EBAF, et al. Progress in childbirthcare in Brazil: preliminary results of two evaluation studies. Cad Saúde Pública [Internet]. 2019 [cited 2020 Mar 12];35(7):e00223018. Available from: https://www. scielo.br/pdf/csp/v35n7/en_1678-4464-csp-35-07-e00223018.pdf

24. Anjos AM, Gouveia HG. Presence of a companion during the process of labor and childbirth: analysis of practice. Rev Enferm UERJ [Internet]. 2019 [cited 2020 Mar 17];27:e38686. Available from: https://www.e-publicacoes.uerj.br/index.php/enfermagemuerj/article/ view/38686/29746

25. Apolinário D, Rabelo M, Wolff LDG, Souza SRRK, Leal GCG. Práticas na atenção ao parto e nascimento sob a perspectiva das puérperas. Rev Rene [Internet]. 2016 [cited 2020 Feb 02];17(1):20-8. Available from: http://www.periodicos.ufc.br/rene/article/view/2601 
26. Wagner HTR. Sobre fenomenologia e relações sociais: Alfred Schutz. Petrópolis: Vozes; 2012.

27. Sanders RA, Crozier K. How do informal information sources influence women's decision-making for birth? a meta-synthesis of qualitative studies. BMC Pregnancy Childbirth [Internet]. 2018 [cited 2020 Jan 29]; 21(18). Available from: https://bmcpregnancychildbirth. biomedcentral.com/articles/10.1186/s12884-017-1648-2

28. Santos CL, Bortoli CFC, Prates LA, Guimarães KB, Massafera Gl, Bisognin P. Preparo e percepções de gestantes sobre as vias de parto. Rev Enferm UFSM [Internet]. 2016 [cited 2020 Feb 15];6(2):186-97: Available from: https://periodicos.ufsm.br/reufsm/article/view/19283/pdf

29. Borrelli SE, Walsh DRM, Spiby HSRN. First-time mothers' expectations of the unknown territory of childbirth: Uncertainties, coping strategies and 'going with the flow'. Midwifery [Internet]. 2018 [cited 2020 Feb 15]; 63:39-45. Available from: https://www.sciencedirect.com/science/ article/abs/pii/S0266613818301281?via\%3Dihub

30. Silva TPR, Dumont-Pena E, Sousa AMM, Amorim T, Tavares LC, Nascimento DCP, et al. Obstetric Nursing in best practices of labor and delivery care. Rev Bras Enferm [Internet]. 2019 [cited 2020 Mar 29];72(Suppl 3):235-42. Available from https://www.scielo.br/pdf/reben/ v72s3/0034-7167-reben-72-s3-0235.pdf

31. Ducan LG, Cohn MA, Chao MT, Cook JG, Riccobono J, Bardacke N. Benefits of preparing for childbirth with mindfulness training: a randomized controlled trial with active comparison. BMC Pregnancy Childbirth [Internet]. 2017 [cited 2020 Mar 29];17(140):1-11. Available from: https://bmcpregnancychildbirth.biomedcentral.com/articles/10.1186/s12884-017-1319-3

32. Silva RCF, Souza BF, Wernet M, Fabbro MRC, Assalin ACB, Bussadori JCC. The satisfaction of the normal delivery: finding oneself. Rev Gaúcha Enferm [Internet]. 2018 [cited 2020 Mar 29];39:e20170218. Available from: https://www.scielo.br/pdf/rgenf/v39/en_1983-1447-rgenf39-e20170218.pdf

33. Whitburn LY, Jones LE, Davey MA, Small R. The meaning of labour pain: how the social environment and other contextual factors shape women's experiences. BMC Pregnancy Childbirth[Internet]. 2017 [cited 2020 Mar 27];17:157. Available from: https:// bmcpregnancychildbirth.biomedcentral.com/articles/10.1186/s12884-017-1343-3

34. Dodou HD, Rodrigues DP, Oriá MOB. The care of women in the context of maternity: challenges and ways to humanize. Rev Pesqui: Cuid Fundam [Internet]. 2017 [cited 2020 Mar 14];9(1):222-30. Available from: http://www.seer.unirio.br/index.php/cuidadofundamental/article/ view/5369/pdf

35. Warmling CM, Fajardo AP, Meyer DE, Bedos C. Práticas sociais de medicalização \& humanização no cuidado de mulheres na gestação. Cad Saúde Pública [Internet]. 2018[cited 2020 Mar 14];34(4):e00009917. Available from: https://www.scielo.br/pdf/csp/v34n4/1678-4464-csp34-04-e00009917.pdf

36. Oliveira VJ, Penna CMM. Every birth is a story: process of choosing the route of delivery. Rev bras Enferm [Internet]. 2018 [cited 2020 Mar 14];71(Suppl 3):1228-36. Available from: https://www.scielo.br/pdf/reben/v71s3/0034-7167-reben-71-s3-1228.pdf 